\title{
Faculty Perspectives on the " $3+3+4$ " Curriculum Reform in Hong Kong: A Case Study
}

\author{
Cecilia K. Y. Chan ${ }^{1} \&$ Lillian Y. Y. Luk ${ }^{1}$ \\ ${ }^{1}$ Centre for the Enhancement of Teaching and Learning, The University of Hong Kong, Hong Kong \\ Correspondence: Cecilia K.Y. Chan, Centre for the Enhancement of Teaching and Learning, Room CPD-1.81, \\ Centennial Campus, The University of Hong Kong, Hong Kong. E-mail: cecilia.chan@cetl.hku.hk
}

\author{
Received: January 29, 2013 Accepted: March 4, 2013 Online Published: March 7, 2013 \\ doi:10.5539/ies.v6n4p56 URL: http://dx.doi.org/10.5539/ies.v6n4p56
}

\begin{abstract}
Curriculum reform in higher education has been taking place in many countries, with much attention paid to many such as the national-level Bologna process in Europe, institutional-level Melbourne Model in Australia and discipline-level Engineering Criteria 2000 (EC2000). This paper gives a detailed account of the reform initiatives taking place in the recent Hong Kong educational system and in particular, focusing on a research-intensive university in Hong Kong through literature and consultations. Being aware that teachers often face challenges in dealing with curriculum changes, this small-scale study aims to identify areas which faculty members require assistance in their professional development by investigating university teachers' perception of the curriculum reform in the Science discipline. Through quantitative and qualitative methods, it was also found that academics expressed doubts towards the implementation of outcome-based and student-centered learning approaches in the new curriculum despite their understanding of these concepts.
\end{abstract}

Keywords: curriculum reform Hong Kong, $3+3+4$, bologna process, graduate attributes, assessment

\section{Introduction}

Curriculum reform involves changes in the educational system, program structures and objectives, leading to changes in approaches to teaching and learning and students' learning outcomes. With an increasing number of graduates becoming mobile global citizens using their education qualifications as vehicles for employment and for further studies outside their home countries, a standardized way of recognizing their qualifications is becoming an urgent requirement within these reforms. In addition, this vehicle also needs to be transferable in different situations and geographical locations, since it is becoming the norm that more students are obtaining employment in areas unrelated to their core area of studies, thus, possessing skills that are transferable for employment regardless of industry is of primarily importance. Reforms are not always accepted favorably by relevant stakeholders. Announcements, consultations, implementation and staff and student development all need to be in place to ensure smooth transition and the process can still produce negative result and criticism. Despite the vast amount of literature on curriculum reform, existing studies (e.g. Muller, Jain, Loeser, \& Irby, 2008; Sunal, Hodges, \& Sunal, 2001) focusing on faculty views of curriculum changes in higher education are scarce. The present study which investigates teacher perception of the curriculum reform in the Science faculty at a research intensive university in south-east Asia, aims to identify areas in which they require assistance in their professional development and address their concerns in order to help facilitate their transition to the new curriculum.

In the section below, we will provide an overview of curriculum reform initiatives in different countries, followed by a literature review on faculty members' perception of curriculum reform.

\subsection{An Overview of Curriculum Reform Initiatives and Their Criticism}

Curriculum reform in higher education has been taking place all around the world at the national-level, institutional-level or discipline-level. These curriculum reforms often focus on the lack of diverse learning experiences, multiple forms of learning pedagogies and assessment, enquiry employing multiple pathways, quality standards and transferable skills which have been lobbied by public demands to introduce curriculum development strategy. In America, the Boyer Commission (1998) report proposed ten ways to change undergraduate education at research universities in America. The report highlighted the importance of 
interdisciplinary education, inquiry-based learning, active learning, and the development of students' communication skills in higher education.

\subsection{The Bologna Process}

The Bologna process in Europe also known as Bologna Accords is probably one of the most renowned curriculum reforms in the recent times. At the signing of the declaration, twenty-nine European countries were involved with the purpose of harmonising the architecture of the European Higher Education system (Sorbonne Joint Declaration, 1998). The Bologna declaration documented six objectives: 1) to adopt a system of easily readable and comparable degrees, 2) to adopt a system based on two-tiered cycles (i.e. a Bachelor-Master structure), 3) to establish a credit system, 4) to promote mobility, 5) to promote European cooperation in quality assurance, and 6) to promote the European dimension in higher education (in terms of curricular development and inter-institutional cooperation) (Reinalda \& Kulesza, 2006). Although 46 European countries have signed the Bologna Declaration by 2007, there were inconsistencies and criticisms with regards to its implementation (European Commission, 2009; Veiga \& Amaral, 2009). In order to adopt a system that allows academic degree standards and quality assurance standards to be more comparable and compatible throughout Europe, a National Qualification Frameworks, which consist of descriptors based on learning outcomes and are defined in terms of qualifications and the European Credit Transfer and Accumulated System (ECTS) credits, were proposed to describe and to clearly express the difference between qualifications obtained at different levels in the new education structure defined in the Bologna Process (European Commission, 2009). However, with reference to the European Commission (2009) report, only about one third of the countries participating in the Bologna process have implemented the frameworks. With the Bologna reform, a large number of undergraduate programmes have been radically reduced or transformed into the new two-tiered system. For example, in Hungary, 1,200 undergraduate programmes were reduced to 135 Bachelor and 190 Master programme (Alesi, Rosznyai, \& Szanto, 2007). However, this move is often criticized as the country's attempt to cut down on education expenditure particularly in staff resources (Charlier \& Croche, 2007). The implementation of the two-tiered system in the Bologna Process involves the unification of programme structure (i.e. 3 years of Bachelor programme and 2 years of Master programme), which resulted in the shortening of undergraduate and graduate years of study. However, various exceptions to the $3+2$ year model were observed. Firstly, although UK is participating in the Bologna process, they continue to use their own model of $3+1$ years of study for a Bachelor programme followed by a Master programme. Secondly, Kehm \& Teichler (2006) pointed out that there are a number of subjects excluded from the $3+2$ year structure. For example, majority of the higher education institutions which participated in the European University Association (EUA) Trends survey indicated that the Bachelor/Master structure does not apply to degrees in medical sciences disciplines such as Dentistry, Medicine and Pharmacy (Sursock \& Smidt, 2010). Sursock \& Smidt (2010) reported that in some countries, both academics and students cast doubts on employers' acceptance of the Bachelor degree under the Bologna process. In response to the Bologna process, students express their concern towards the introduction of tuition fees, the possibility of the new curriculum becoming more rigid and the reduced duration of studies which may make it difficult for them to engage in internship and/or part-time job (Gross, 2010). Problems were also observed with the introduction of the European Credit Transfer and Accumulation System (ECTS) at the national level. According to the European Commission (2009) report, although there is substantial development in the implementation of ECTS, differences can be observed in institutions' definition of credits. It was found that while institutions in some countries (e.g. Denmark) use both learning outcomes and student workload as a reference to define credits, institutions in other countries (e.g. Poland) use contact hours or a combination of contact hours and student workload as a reference to define credits. In another words, there seems to be a lack of agreement on the basis of a credit system (Kehm \& Teichler, 2006).

In addition to the unification of programme structure and the regulation of credit requirement, the introduction of the Diploma Supplement (DS) is also a move to facilitate student mobility within Europe. The European Commission, the Council of Europe and UNESCO (2009) jointly developed a DS template, thus, every graduate in their respective countries should receive a DS, which "provides a description of the nature, level, context, content and status of the studies that were successfully completed by an individual" (p.31). However, in a project conducted by Aelterman et al. (2008), which compared DS samples collected from different European countries, it was found that the samples vary in terms of structure and content. Moreover, the credit system and the DS were criticized by Wächter (2004) as being conversion instruments aiming at creating a convertible system, rather than a unified system.

\subsection{The Melbourne Model}

Following the Bologna model, the University of Melbourne adopted the 'Melbourne Model' in 2008, which also 
involves a reduction in the number of undergraduate degrees available. 96 original undergraduate degrees were reduced to six "new generation" degrees at the institutional-level (Davies \& Devlin, 2007). The "new generation" degrees aim to help students develop a broad interdisciplinary knowledge base and a deep core disciplinary knowledge base (The University of Melbourne, 2006). Thus, in addition to enrolling in core major courses, students are also required to enroll in 'breadth' courses, outside their major area of study. Similar to Bologna model's ' $3+2$ ' approach, students were required to complete 3 years of undergraduate studies, followed by a 2 years Masters degree for professional qualifications.

Supporters of the Melbourne Model suggest that the broader undergraduate curriculum and more sophisticated professional education will produce more rounded graduates who are more likely to be able to cope with complex challenges as a result of changing economic, political and social environment in the 21 st century. They also argue that the new curriculum will offer students more choices and more time to make decisions. On the contrary, people who oppose the Melbourne Model argue that the model delays students' career decision. In a commentary, King (2011), Dean of the Faculty of Business and Economics at Monash University questioned the Melbourne Model and emphasized that the traditional tertiary education system allows students to try out different areas of specializations at the undergraduate level before deciding on further studies. However, with the Melbourne model, students may end up enrolling in a Master level course in an area which they are unfamiliar with. From the students' perspective, some are concern that the Melbourne Model may leave them with a financial burden after spending more time studying before entering the workforce (Gooch, 2011), while some are worried about being forced to take courses which they are not interested in (Coleridge, 2008). From the teachers' perspective, many fear job losses as a result of the reduction in existing undergraduate degrees (Morton \& Tomazin, 2007).

\subsection{The Accreditation Board for Engineering and Technology (ABET) Criteria 2000}

Apart from the European-wide reform and the Melbourne University reform, educational reform has also been taking place on the disciplinary level fuelled by academics, employers and government. In the United States, the Accreditation Board for Engineering and Technology (ABET) developed the Engineering Criteria 2000 (EC2000), which shifted the basis for accreditation of engineering programmes from the previous detailed procedural specifications and curriculum content to learning outcomes (Prados, Peterson, \& Lattuca, 2005). This approved EC2000 was initiated and recommended by more than 125 individuals, including university presidents, deans, and faculty members; industry leaders; private practitioners; professional and technical society liaisons and executive directors; state registration board members; and government researchers and regulators in technical fields together with ABET leaders, commissioners, and board members through long series of workshops. Previous accreditation standards used to focus on the development of disciplinary knowledge. Recognizing the importance of the development of generic skills in undergraduates, EC2000 now emphasizes on the development of generic skills, such as communication skills and the ability to work as a team (Lattuca, Terenzini, \& Volkwein, 2006). Within the course of the degree, students are expected to demonstrate their ability and apply their knowledge in engineering design and at the same time, incorporate engineering standards and constraints as encountered in industries such as economic, environmental, sustainability, manufacturability, ethical, health and safety, social, and political. With the co-operations from Deans, academics and employers in the US, positive changes in student experiences, learning outcomes and employers' perspectives were collected and evaluated by ABET (Lattuca, Terenzini, Volkwein, \& Peterson, 2006). Apart from the EC2000, in 1989 ABET and accreditation bodies from six different countries agreed to sign a Washington Accord to facilitate the mobility of the increasingly global profession.

\subsection{The Hong Kong Curriculum Reform " $3+3+4$ "}

Curriculum reform in the 20th century, no matter country-based, institution-based or discipline-based, aims to provide students with student-centered and multidisciplinary learning experiences but more importantly, it intends to add breadth to depth and to improve the generic skills of students on their non-academic achievement to prepare the students for a complex, mobile and challenging work environment. In the case of Hong Kong, a major national educational reform, known as the " $3+3+4$ " was initiated in 2006 . The new academic structure places strong emphases on four elements, namely student-centred learning experiences, life-long learning experiences, providing students with multiple pathways for learning and whole person development. Under the new education system, the duration of secondary schooling was reduced from seven to six years, such that students spent three years in junior secondary and three years in senior secondary. This structure change in the secondary school system will be followed by a change in the higher education system from a three-year undergraduate curriculum to a four-year curriculum. The rationale behind this change is to further align with the educational system in China, North America and Australia to allow better mobility for Hong Kong graduates to 
pursue further studies or to work aboard. It is important to note that under the old system, not every student had the opportunity to continue their study into the two senior secondary years. In fact, only one-third of the students who sat for the HKCEE exams would get the chance to continue their study. With the proposed system, every student will be given the opportunity for six years of secondary schooling. The proposed new academic structure also includes the elimination of public assessments for the allocation of students into secondary schools and the elimination of the streaming of students into arts and science tracks in secondary school. Many academics have advocated for years to evade premature subject streaming. This narrow focus has resulted in some students being incapable of understanding or discussing basic issues on either one of the subject areas. In addition, students under the " $3+3+4$ " will only be require to sit for one national public examination known as the Hong Kong Diploma in Secondary Education (HKDSE) at the end of year six. Previously, students have to sit for two external public examinations, one at the end of year five known as the Hong Kong Certification of Education Examination (HKCEE) and the other one at the end of year seven known as the Hong Kong Advanced Level Examination (HKALE). This examination arrangement may help to simplify the university admission process for students, and alleviate the added stress of having to prepare for two separate examinations. However, now with only one public examination, there is criticism that students will no longer have the first examination acting as a filter, and in addition, students may not have enough experience in public examination.

Under the new system, students in secondary education are expected to take four core subjects namely Mathematics, English language, Chinese language and Liberal Studies. The decision and design of the Liberal Studies curriculum as a core subject has aroused many public debates. Previously, Liberal Studies was only an elective subject. As a result, it has taken some hurdles and many consultation sessions to get consensus and support of parents, students, education professionals and the general public. The aims for including Liberal Studies as a core subject are "to enhance students' awareness of contemporary issues, broaden the knowledge base and expanding the perspectives of students, as well as strengthen student's critical thinking skills" which aligns with the primary aim of the $3+3+4$ curriculum reform (The Curriculum Development Council and the Hong Kong Examinations and Assessment Authority, 2007). Some teachers would have experience in teaching Liberal Studies as it was previously an elective subject. However, with the modification and extension of the liberal studies curriculum, significant training would be required even for these teachers. And with the learning and teaching approach structured around inquiry-based, even if teachers are well-trained, students who have not been previously taught or assessed by this method may find it difficult to adapt the inquiry approach. This is not something they can get accustomed to easily, it may take years to learn and adapt, from the traditional spoon-fed learning approach. With the introduction of outcomes-based to student learning approach and the use of standards-referenced reporting, the change in format of external examination adds burden on teachers and students in the transition cohorts. For teachers, designing new mock examination papers may become more difficult and time-consuming, as they are accustomed to the old examination methods.

In addition to the four core subjects, students have to take two or three electives and other Learning Experiences that complement and support the students' academic learning, often these learning experiences are out of class experiences. For the elective subjects, students may opt to take on Applied Learning courses (ApL) which are more career and skill-oriented with stronger elements of practical learning linked to broad professional and vocational fields.

With similar aims as the curriculum reform within the secondary education system, the requirements of Hong Kong higher education curriculum reform follow the same quality standards. The new curriculum will continue to develop student-centered learning experiences, such that all higher education institutions funded by the University Grant Committee (UGC) of Hong Kong will adopt an Outcomes-Based Approach to Student Learning (OBASL) as the teaching and learning approaches at the university, programme and course levels (University Grants Committee, 2010).

\section{Literature Review on Faculty's Perception of Curriculum Reform}

There is a general agreement in the literature that teachers play an important role in bringing changes into classrooms, and thus are the "change agents" of curriculum reforms. Studies have found that the beliefs and attitude of teachers have a significant influence on the success of curriculum implementation. For instance, in Cronin-Jones's (1991) study which investigated the beliefs of middle school Science teachers, it was found that having teachers with a positive attitude towards the content of the curriculum enhances its implementation. Since teachers' beliefs influences the success of curriculum implementation, it is important for us to understand teachers perception of the curriculum reform initiatives taking place at the educational institution which they are working at. 
Research on teachers' perception of curriculum reform has been conducted at both the school and university level. Generally, teachers often report mixed feelings towards new curriculum arrangement (Handal \& Herrington, 2003). Another common finding is that teachers perceive an increase in workload and a lack of support in the process of change (Bantwini, 2010; Flores, 2005). In addition, Sunal et al. (2001) found that teachers' existing conception of teaching and learning often act as barriers to change.

While previous studies mentioned above were based on the Western context, Cheung \& Wong (2012) investigated the barriers and challenges perceived by school teachers during the early stage of the curriculum reform in Hong Kong. Similar to the findings on teachers' perception of curriculum reform initiatives conducted in other countries, the authors found that heavy workload and a lack of understanding of the curriculum reform were common obstacles encountered by school teachers. While Cheung \& Wong's (2012) study was on teachers' perception of curriculum reform initiatives taking place in primary and secondary schools, the current study is on faculty members' perception of the curriculum reform initiatives taking place in a Hong Kong university.

\section{Methodology}

This small case study draws on quantitative and qualitative data on faculty perspectives of the curriculum reform which was collected by a questionnaire administered to 60 faculty members in the Science faculty at the University of Hong Kong (HKU). Table 1 provides some background information of the participants.

Table 1. Demographics of the survey participants

\begin{tabular}{lclc}
\hline Background information & $\mathbf{\%}$ & Background information & \% \\
\hline Position & & Department & 19.7 \\
Professor & 19.7 & Biological Sciences & 9.8 \\
Associate Professor & 39.3 & Chemistry & 19.7 \\
Assistant Professor & 26.2 & Earth Sciences & 18.0 \\
Teaching Consultant & 14.8 & Mathematics & 14.8 \\
Status & & Physics & 18.0 \\
Tenured & 52.5 & Statistics and Actuarial Science & \\
Non-tenured & 47.5 & & \\
\hline
\end{tabular}

The questionnaire was developed to assess teachers' perception of the curriculum reform in the university. It consisted of 11 items exploring teachers' perception of teaching in relation to the curriculum reform, rated on a 5-point Likert scale with one being "strongly agree" and five being "strongly disagree". In this study, the research hypothesis was defined as: Practitioners' are fully aware of the implications of the new $3+3+4$ curriculum to their teaching. Examples of the questionnaire items on teachers' attitude towards the curriculum reform were: "I am fully aware of the six university aims in implementing the curriculum reform", "I think the curriculum reform will benefit our students in their learning experience", "I will enjoy the challenges of the curriculum reform". The quantitative data obtained was analyzed using Statistic Package for the Social Science (SPSS).

The last item on the questionnaire was an open-ended question asking participants to give their opinion on what they believe to be relevant to teaching and learning in the Faculty. From the qualitative feedback collected, we identified some comments related to the curriculum reform.

Before looking at the result of our data analysis, we will first give a detailed account on the reform initiative taking place in HKU.

\section{Case Study: The University of Hong Kong (HKU) Curriculum Reform}

For a research intensive university like the University of Hong Kong (HKU), there has been a massive revamp in its philosophy of teaching and learning. The leading change was the appointment of its first Teaching and Learning Pro-Vice Chancellor. This paved the scene on the importance of teaching and learning in Hong Kong higher education. The subsequent step was the development and approval of the HKU educational aims by the HKU Senate in 2008. These six aims lay the foundation on which the programmes and courses should be designed and developed in the 4-Year curriculum - the learning outcomes which shape the graduates. The six 
HKU aims are shown in table 2.

To accomplish the proposed official requirements, HKU has introduced a number of initiatives in preparation for the new 4-Year curriculum. This included setting up a teaching and learning working group for the 4-Year curriculum and subsequently, seven steering committees were set up to deal with challenges arising from the Academic Advisory system, Assessment, Diverse Learning experiences, IT in Curriculum, Language across the Curriculum, Staff Engagement and Staff Development and Student Learning Experiences. In order to undertake these initiatives, the Centre for the Enhancement of Teaching and Learning (CETL) has been actively involved in the " $3+3+4$ " curriculum reform, playing a supportive role in the development of outcomes-based approaches to student learning and assessment. The centre offers courses on teaching and learning, which aim to enhance staff members' understanding of issues related to the new curriculum. The centre also organizes workshops and seminars which provide staff members with an opportunity to share good teaching practices and research findings on teaching and learning in higher education. In addition, an one-day induction on teaching and learning and a more advanced three-day programme on outcomes-based approach to student learning were introduced for new academic staff members. These two programmes have since passed through the Teaching and Learning quality committee and have became mandatory for all new academic staff. Similarly, all postgraduate students who have been given teaching or tutoring duties are expected to enroll in a six-week ( 24 contact hours) teaching certificate course. Of course, there are some criticisms towards these courses. With the postgraduate teaching certificate, Deans have expressed their concerns in overloading the postgraduate students. They mentioned that there are graduate courses, research courses and now teaching and learning courses that the postgraduate students are required to take; their primary intention of doing research is being astray. Although there are some criticisms towards these courses and programmes, in general, participants' feedback has been positive.

Table 2. HKU educational aims

\section{HKU Educational Aims}

The new undergraduate curriculum at HKU is designed to enable our students to develop their capabilities in:

- Pursuit of academic/professional excellence, critical intellectual enquiry and life-long learning

- Tackling novel situations and ill-defined problems

- Critical self-reflection, greater understanding of others, and upholding personal and professional ethics

- Intercultural understanding and global citizenship

- Communication and collaboration

- Leadership and advocacy for the improvement of the human condition

Under the Hong Kong higher education curriculum reform, universities were to develop whole person and all-rounded education with the introduction of the additional year. Thus, the new undergraduate curriculum will focus on subjects outside one's major, general education and lifelong learning skills, which were limited in the three-year curriculum (Chan, 2012a). Within the three-year curriculum at HKU, students were only required to take 12 credits of Common Core courses (i.e. interdisciplinary courses outside one's major). But in the four-year curriculum, it has allowed students to undertake 36 credits of such courses. These courses are not based on and may not be related to their majors. The common core courses use diverse mode of pedagogy and assessment and are targeted on four main areas of inquiry, namely, Scientific and Technological Literacy, the Humanities, China: Culture, State and Society and Global Issues. The Common Core (2012) curriculum "focuses on issues that have been, and continue to be, of deeply profound significance to humankind, the core intellectual skills that all HKU undergraduates should acquire and the core values that they should uphold" (p.4). However, there were questions about the type of courses suitable for the Common Core and the appropriate level of breadth and depth in these courses.

Assessment is important to student and to teacher, this claim is indisputable. At HKU, a bold and daring act was 
asserted; an Assessment policy at HKU was passed by Senate in 2009. In the policy, there were a number of changes such as the abandonment of norm referencing to standard referencing, clear standards descriptors to be written and explicitly stated and communicated with students and teachers, providing feedback and the employment of diverse forms of assessment in all courses (Chan, 2012b) to ensure good balance of learning experiences.

The first cohort of the New Senior Secondary School Curriculum will graduate in the year 2012 along with the graduates from the old "Form 7" matriculation education structure. Thus, by September 2012, student numbers in the first years at all the universities in Hong Kong will increase by $50 \%$ due to the admission of this double cohort. This double cohort, an estimate of 29,000 students is a great challenge and concern for all Hong Kong tertiary education institutions. This will tax institutions severely, starting with admissions. With the new curriculum structure and new examination process, parents and students are concerned with the unfamiliar and fairness of the admission process and are worry about tougher competition for admission due to the double cohort despite there should be double the number of first-year-first-degree (FYFD) places. This whole new process will of course be in the eyes of the general public and may be judged severely. Thus, it is vital that the transition to the new undergraduate system runs smoothly.

The new undergraduate curriculum offers a lot of opportunities for higher education development, however, these changes does not come without cost. In particular, the changes that are taking place at the universities, such as the building of new infrastructures to accommodate the double cohort, are expensive. Staff members also have to deal with possible increase in workload as a result of preparation for the new curriculum. The cost of curriculum reform often brings about criticisms. In order for us to gain a better understanding of the changes taking place at the university, it is necessary for us to investigate the validity of criticisms by seeking feedback from staff members and students, who are experiencing the changes.

\section{Results}

The results are shown in table 3. Majority (70\%) of the participants were aware of the university aims in the curriculum reform, while $16.6 \%$ disagreed. However, $36.6 \%$ of the participants disagreed that their role in the implementation of the new curriculum has been clearly defined to them, while $28.3 \%$ agreed. $35 \%$ held neutral opinion. This suggests that teachers have not been given clear instructions on the role they have to play in curriculum reform. On the other hand, only $41.6 \%$ of the participants believed that the curriculum reform will benefit students in their learning experience, while $30 \%$ disagreed. $28.3 \%$ of the participants held neutral opinion. $66.7 \%$ of the participants reported that they understand the concept of outcome-based learning, while $23.3 \%$ disagreed. $10 \%$ of the participants held neutral opinion. Despite their perceived understanding of outcome-based learning, majority (62.7\%) of the participants mentioned that they would like to receive training in outcome-based approaches to student learning. Although most of the academic staffs in our study are keen towards learning about outcome-based learning, $48.3 \%$ of the participants indicated that they were concerned that the new curriculum, geared towards student-centered learning, may make it difficult for them to cover all the content of the courses. This suggests that teachers perceive some contradiction between student-centered learning and the quantity of course content. In fact, $81.8 \%$ of the participants mentioned that they expect their teaching workload to increase as a result of the curriculum reform, suggesting that most teachers perceive an increase in teaching workload as a major challenge related to the curriculum reform.

$40 \%$ of the participants indicated that they enjoy the challenges of the curriculum reform, while $20 \%$ disagreed. $40 \%$ of the participants held neutral attitude. Significant correlation was found between teachers' perception of the challenges of the curriculum reform and 1$)$ their awareness of university aims $(r=.399, p<.01), 2)$ keenness to receive training in outcome-based approaches to student learning $(r=.326, p<.05)$, and 3 ) awareness of the role of the common core curriculum $(r=.313, p<.05)$. This suggests that teachers who believe that they will enjoy the challenges of the curriculum reform also tended to be aware of the university aims and the role of the common core curriculum, and are keen towards staff development.

$66.1 \%$ of the participants reported that they are aware of the role that common core courses will play in the curriculum reform at $\mathrm{HKU}$, while $16.2 \%$ are not aware and $14.5 \%$ held neutral opinion. And more than $64 \%$ of the participants are considering contributing to the common core curriculum as part of their duties in the new curriculum.

Out of the 60 participants, 15 responded to the open-ended question and $46.7 \%(n=7)$ of the comments focused on student evaluation of teaching (SET) under the curriculum reform. It was found that teachers perceive a lack of interest among students towards the use of new approaches to teaching (i.e. outcome-based and student centered learning approaches): 
'I believe the students prefer to be spoon-fed and get easy concrete material, and many faculties focus this way to get high SET scores...'

Table 3. Survey results

\begin{tabular}{|c|c|c|c|c|c|c|}
\hline \multirow[b]{2}{*}{$\begin{array}{l}\text { Items on the curriculum reform } \\
\qquad(n=60)\end{array}$} & \multicolumn{6}{|c|}{ Frequency $(\%)$} \\
\hline & 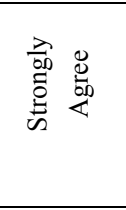 & 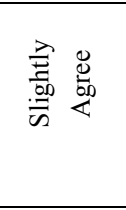 & $\overline{\widetilde{E}}$ & 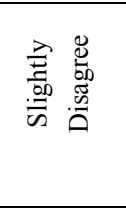 & 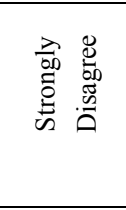 & 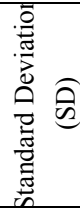 \\
\hline $\begin{array}{l}\text { I am aware of the } 6 \text { HKU aims in the " } 3+3+4 " \\
\text { curriculum. }\end{array}$ & $24(40.0)$ & $18(30.0)$ & $8(13.3)$ & $5(8.3)$ & $5(8.3)$ & 1.273 \\
\hline I understand the concept of Outcome Based Learning & $18(30.0)$ & $22(36.7)$ & $6(10.0)$ & $6(10.0)$ & $8(13.3)$ & 1.368 \\
\hline $\begin{array}{l}\text { I am concerned that teaching younger students may } \\
\text { require additional skills that I have not had a chance } \\
\text { to develop. }\end{array}$ & $5(8.3)$ & $16(26.7)$ & $19(31.7)$ & $11(18.3)$ & $9(15.0)$ & 1.185 \\
\hline $\begin{array}{l}\text { I am concerned that the new curriculum is geared } \\
\text { towards student-centered learning and this will make } \\
\text { it difficult for me to cover all the content of my } \\
\text { courses. }\end{array}$ & $11(18.3)$ & $18(30.0)$ & $20(33.3)$ & $9(15.0)$ & $2(3.3)$ & 1.064 \\
\hline $\begin{array}{l}\text { I think the Curriculum Reform will benefit our } \\
\text { students in their learning experience. }\end{array}$ & $8(13.3)$ & $17(28.3)$ & $17(28.3)$ & $9(15.0)$ & $9(15.0)$ & 1.258 \\
\hline I enjoy the challenges of the Curriculum Reform. & $7(11.7)$ & $17(28.3)$ & $24(40.0)$ & $4(6.7)$ & $8(13.3)$ & 1.157 \\
\hline $\begin{array}{l}\text { I expect my teaching workload to increase as a result } \\
\text { of the curriculum reform. }\end{array}$ & $17(28.3)$ & $32(53.3)$ & $10(16.7)$ & $1(1.7)$ & $0(0.0)$ & 0.72 \\
\hline $\begin{array}{l}\text { My role in implementation of the new curriculum has } \\
\text { been clearly defined to me. }\end{array}$ & $5(8.3)$ & $12(20.0)$ & $21(35.0)$ & $11(18.3)$ & $11(18.3)$ & 1.20 \\
\hline $\begin{array}{l}\text { I am aware of the role that common core courses will } \\
\text { play in the reformed curriculum. }\end{array}$ & $19(31.7)$ & $22(36.7)$ & $9(15.0)$ & $4(6.7)$ & $6(10.0)$ & 1.26 \\
\hline $\begin{array}{l}\text { I consider contributing to the common core } \\
\text { curriculum should be part of my duties in the future. }\end{array}$ & $13(21.7)$ & $27(45.0)$ & $13(21.7)$ & $3(5.0)$ & $4(6.7)$ & 1.078 \\
\hline
\end{tabular}

Items on the curriculum reform

$$
(n=59)
$$

I would like to receive training in outcome-based approaches to student learning
Yes

No

\section{Conclusions}

This paper began with an introduction to the curriculum reform initiatives in different countries, followed by a detailed account of the Hong Kong education system and its challenges and changes in the curriculum reform " $3+3+4$ ". The author focused on the changes taking place in one particular university and reported the changes and staff opinion in a particular discipline (i.e. Science) towards these changes. Generally, findings of this study support the research hypothesis, such that Science teachers who participated in our study are aware of the implications of the new curriculum to their teaching.

Consistent with findings from previous studies (e.g. Handal \& Herrington, 2003; Bantwini, 2010) on teachers' 
perception of curriculum reform, Science teachers in our study reported mixed feelings towards the new university curriculum and perceive an increase in workload as a result of reform initiatives. Contrary to the study by Cheung \& Wong (2012), which found inadequate understanding of the curriculum reform among school teachers in the Hong Kong context, majority of our participants reported an understanding of outcome-based learning and common core courses, which are major components of the new university curriculum.

From the results, there is a general concern that the reformed curriculum may not bring true benefits to the students. Most academics in Hong Kong have been taught through the traditional didactic way of teaching during their own school years, and very few would have taken courses on teaching and learning prior to the curriculum reform. Despite of the many researches and studies on student-centred learning and active learning approaches which provided positive evidences on enhancing student learning experience that encourage deep learning (Lizzio, Wilson, \& Hadaway, 2007; Lizzio, Wilson, \& Simons, 2002; Trigwell \& Prosser, 2004; Wilson \& Fowler, 2005), it is difficult to shift that frame of mind from being the teacher who "knows-it-all" to a teacher who only facilitates learning to allow students to explore. . Thus, it shows that even if academics understand the concepts of OBASL, it does not necessary mean they agree with the concept or will implement the approach. And the exploratory style of pedagogical learning such as inquiry approach may leave the teacher feeling "out of control", and is not always welcome by all academics. Academics believe that content must be covered to provide the breadth and the depth. Thus, about half of the participants believed that changes towards the outcomes-based approach and a more student-centred learning using diverse forms of pedagogies and assessment approach may hinder their progression in covering all the topics in a course. Our findings also suggest that academics' perceived lack of interest among students towards the new approaches of teaching is another reason for their hesitation in implementing them (Chan, Zeng, Luk, \& Lee, submitted).

On the other hand, teachers are interested in purposing new common core courses at HKU. The common core curriculum allows teachers to purpose new courses that are of interest to society and everyday lives. There is a lot of autonomy in the learning outcomes, pedagogies and assessment. Teachers are encouraged and can propose $100 \%$ continuous assessment using various forms and styles of learning (Porter, King, Goodkin, \& Chan, 2012). The common core curriculum also gives a sense of status and a small teaching development grant to teachers who are successfully chosen on their course.

Changes are never easy. Being a research-intensive university like HKU, the changes from the curriculum reform is a big step forward and the start of an era that points towards the importance of teaching and learning. Time will influence how the stakeholders understand and accept the curriculum and its changes. The mentality of teachers and students will change in due course. Thus, the results of this study is heavily determined by the timeframe and timing. Any curriculum reform requires constant feedback and renewal to enhance student learning.

It is vital to prepare the teachers in any curriculum reform. As mentioned before, many reforms are initiatives of top-down approaches, but if there is no support from the bottom-up or middle management to implement the curriculum "properly", these changes will not occur. The curriculum reform should be done in consultations with all stakeholders at all levels irrespective of ranks. The successfulness and challenges of Hong Kong's curriculum reform are determined by those who lead, implement and teach it.

\section{References}

Aelterman, G., Curvale, B., Erdoğan, A., Helle, E., Kärki, S., \& Miles, C., et al. (2008). Study on the dilpoma supplement as seen by its users. Retrieved Feb. 6, 2012, from http://www.enqa.eu/files/Diploma\%20Supplement\%20Study_Edit\%20MS.pdf

Alesi, B., Rosznyai, C., \& Szanto, T. (2007). The implementation of bachelor and master programmes in $\begin{array}{llll}\text { Hungary. } & \text { European Journal of }\end{array}$ http://dx.doi.org/10.1111/j.1465-3435.2007.00316.x

Bantwini, B. D. (2010). How teachers perceive the new curriculum reform: Lessons from a school district in the Eastern Cape Province, South Africa. International Journal of Educational Development, 30(1), 83-90. http://dx.doi.org/10.1016/j.ijedudev.2009.06.002

Chan, C. K. Y. (2012a). Assessment for community service types of experiential learning in the engineering discipline. European Journal of Engineering Education, 37(1), 29-38. http://dx.doi.org/10.1080/03043797.2011.644763 
Chan, C. K. Y. (2012b). Identifying and understanding the graduate attributes learning outcomes in a case study of community service experiential learning project. International Journal of Continuing Engineering Education and Life-long Learning, 22(1/2), 148-159. http://dx.doi.org/10.1504/IJCEELL.2012.047040

Chan, C. K. Y., Zeng, L. M., Luk, L. Y. Y., \& Lee, E. C. S. (submitted). What is the teachers' perception towards student evaluation of teaching in Hong Kong. Teaching in Higher Education.

Charlier, J. E., \& Croche, S. (2007). The Bologna process: The outcome of competition between Europe and the United States and a stimulus to this competition. European Education, 39(4), 10-26. http://dx.doi.org/10.2753/EUE1056-4934390401

Cheung, A. C. K., \& Wong, P. M. (2012). Factors affecting the implementation of curriculum reform in Hong Kong: Key findings from a large-scale survey study. International Journal of Educational Management, 26(1), 39-54. http://dx.doi.org/10.1108/09513541211194374

Common Core. (2012). Common core curriculum: Student handbook 2012-2013. Hong Kong: The University of Hong Kong. Retreved March 6, 2012, from http://commoncore.hku.hk/files/cc12_lowres.pdf

Coleridge, B. (2008). Why the Melbourne Model is failing students. Eureka Street. Retrieved Feb. 7, 2012, from http://www.eurekastreet.com.au/article.aspx?aeid=10652

Davies, M., \& Devlin, M. (2007). Interdisciplinary higher education and the Melbourne Model. Paper presented at the Philosophy of Education Society of Australasia Annual Conference.

European Commission. (2009). Higher education in Europe 2009: Developments in the Bologna process. Brussels: Education Audiovisual \& Culture Executive Agency (EACEA).

Flores, M. A. (2005). Teachers' views on recent curriculum changes: Tensions and challenges. Curriculum Journal, 16(3), 401-413. http://dx.doi.org/10.1080/09585170500256479

Gooch, L. (2011). Adding 'breadth' to specialist degrees in Australia. The New York Times. Retrieved Jan. 29, 2012, from http://www.nytimes.com/2011/06/20/world/asia/20iht-educLede20.html?pagewanted=all

Gross, M. (2010). Bologna resistance. Current Biology, 20(2), R39-R40. http://dx.doi.org/10.1016/j.cub.2010.01.004

Handal, B., \& Herrington, A. (2003). Mathematics teachers' beliefs and curriculum reform. Mathematics Education Research Journal, 15(1), 59-69. http://dx.doi.org/10.1007/BF03217369

Kehm, B. M., \& Teichler, U. (2006). Which direction for bachelor and master programmes? A stocktaking of the

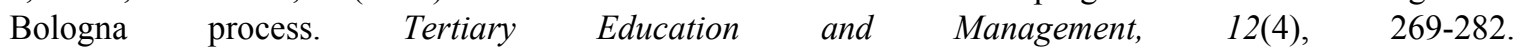
http://dx.doi.org/10.1080/13583883.2006.9967173

King, S. (2011). Undergraduate education and the Melbourne Model. The Conversation. Retrieved Feb. 6, 2012, from http://theconversation.edu.au/undergraduate-education-and-the-melbourne-model-993

Lattuca, L. R., Terenzini, P. T., \& Volkwein, J. F. (2006). Engineering change: A study of the impact of EC2000. Baltimore: ABET, Inc.

Lattuca, L. R., Terenzini, P. T., Volkwein, J. F., \& Peterson, G. D. (2006). The changing face of engineering education. The Bridge: Linking Engineering and Society, 36(2), 5-14.

Lizzio, A., Wilson, K., \& Hadaway, V. (2007). University students' perceptions of a fair learning environment: a social justice perspective. Assessment and Evaluation in Higher Education, 32(2), 195-213. http://dx.doi.org/10.1080/02602930600801969

Lizzio, A., Wilson, K., \& Simons, R. (2002). University students' perceptions of the learning environment and academic outcomes: implications for theory and practice. Studies in Higher Education, 27(1), 27-52. http://dx.doi.org/10.1080/03075070120099359

Morton, A., \& Tomazin, F. (2007). New model could cut academic jobs. The Age Retrieved Feb. 14, 2012, from http://www.theage.com.au/articles/2007/04/17/1176696837320.html

Muller, J. H., Jain, S., Loeser, H., \& Irby, D. M. (2008). Lessons learned about integrating a medical school curriculum: Perceptions of students, faculty and curriculum leaders. Medical Education, 42(8), 778-785. http://dx.doi.org/10.1111/j.1365-2923.2008.03110.x

Porter, G., King, J. A., Goodkin, N. F., \& Chan, C. K. Y. (2012). Experiential learning in a common core curriculum: Student expectations, evaluations, and the way forward. International Education Studies, 5(3), 24-38. http://dx.doi.org/10.5539/ies.v5n3p24 
Prados, J. W., Peterson, G. D., \& Lattuca, L. R. (2005). Quality assurance of engineering education through accreditation: The impact of Engineering Criteria 2000 and its global influence. Journal of Engineering Education, 94(1), 165-184. http://dx.doi.org/10.1002/j.2168-9830.2005.tb00836.x

Reinalda, B., \& Kulesza, E. (2006). The Bologna process: Harmonizing Europe's higher education, including the essential original texts (2nd ed.). Opladen: Budrich.

Sorbonne Joint Declaration. (1998). Joint declaration on harmonisation of the architecture of the European higher education system. Retrieved June 8, 2012, from http://www.bologna-berlin2003.de/pdf/Sorbonne_declaration.pdf

Sunal, D. W., Hodges, J., \& Sunal, C. S. (2001). Teaching science in higher education: Faculty professional development and barriers to change. School Science and Mathematics, 101(5), $246-257$. http://dx.doi.org/10.1111/j.1949-8594.2001.tb18027.x

Sursock, A., \& Smidt, H. (2010). Trends 2010: A decade of change in European higher education. Belgium: European University Association (EUA).

The Boyer Commission. (1998). Reinventing undergraduate education: A blueprint for America's research universities. Stony Brook, NY: SUNY Stony Brook.

The Curriculum Development Council and the Hong Kong Examinations and Assessment Authority. (2007). Liberal studies curriculum and assessment guide (Secondary 4-6). Retrieved June 8, 2012, from http://www.edb.gov.hk/FileManager/EN/Content_5941/ls_e_070307.pdf

The University of Melbourne. (2006). The Melbourne Model: Report of the curriculum commission. Melbourne: The University of Melbourne.

Trigwell, K., \& Prosser, M. (2004). Development and use of the approaches to teaching inventory. Educational Psychology Review, 16(4), 409-424. http://dx.doi.org/10.1007/s10648-004-0007-9

University Grants Committee. (2010). Aspirations for the higher education system in Hong Kong. Retrieved Jan. 27, 2012, from http:/www.ugc.edu.hk/eng/doc/ugc/publication/report/her2010/her2010-rpt.pdf

Veiga, A., \& Amaral, A. (2009). Survey on the implementation of the Bologna process in Portugal. Higher Education, 57(1), 57-69. http://dx.doi.org/10.1007/s10734-008-9132-6

Wächter, B. (2004). The Bologna Process: Developments and prospects. European Journal of Education, 39(3), 265-273. http://dx.doi.org/10.1111/j.1465-3435.2004.00182.x

Wilson, K., \& Fowler, J. (2005). Assessing the impact of learning environments on students' approaches to learning: Comparing conventional and action learning designs. Assessment and Evaluation in Higher Education, 30(1), 87-101. http://dx.doi.org/10.1080/0260293042003251770 